Ryszard A. Stefański

Lazarski University in Warsaw, Poland

ORCID: 0000-0003-0995-9499

ryszard.stefanski@lazarski.pl

\title{
The Preventive Nature of Restraining Orders, Contact Prohibition Orders and Publication Prohibition Orders of Information about Medical Staff Members or Persons Assigned to Assist Medical Staff Members
}

\author{
Środek zapobiegawczy zakazu zbliżania się na wskazaną odległość, \\ zakazu kontaktów lub zakazu publikacji w stosunku do członka \\ personelu medycznego lub osoby przybranej mu do pomocy
}

\section{ABSTRACT}

The article has an investigative nature and analyzes new preventive measure introduced by the Act of 31 March 2020, applicable to the accused of crime committed towards member of medical staff or to the person cooperating with medical staff in relation to the medical care activity performed. The main scientific goal of the article is to prove that such measure, besides critical opinions, can have an important role in assuring safety to medical staff, although such goal is not adequate to main goals of preventive measures, as well as to indicate necessary legislative modifications which should eliminate discrepancies due to its defective regulation. The result of investigation is original, because demonstrates the need of intervention of the legislator, despite the regulation is pretty recent. The investigation has been conducted on national level, but can be useful for other states, as it relates to the original preventive measure which exceed the traditional understanding of such measures. It is important for science, because it contains profound dogmatic analyses, presents an important load of theory. It is also important for the practice, as it indicates the interpretative direction of premises of this measure and other its elements, which can be helpful for its homogenous application.

Keywords: medical staff members; medical care; persons assigned to assist; preventive measure; contact prohibition; publication prohibition; restraining orders

CORRESPONDENCE ADDRESS: Ryszard A. Stefański, PhD, Prof. Dr. Habil., Full Professor, PhD, Lazarski University (Warsaw), Faculty of Law and Administration, Department of Criminal Law, ul. Świeradowska 43, 02-662 Warszawa, Poland. 


\section{INTRODUCTION}

The Act of 31 March 2020 amending the Act on special solutions related to the prevention, counteracting and combating of COVID-19, other infectious diseases and related crisis situations, and certain other acts, ${ }^{1}$ complemented the catalog of preventive measures by adding restraining orders, contact prohibition orders and publication prohibition orders, including via IT systems or telecommunications networks, of information or content that affects the legally protected interests of the aggrieved party. The prohibition applies to persons accused of committing an offense against a medical staff member in connection with the performance of their care activities, against a person assigned to assist medical staff in their performance of these activities (Article 276a $\S 1$ of the Code of Criminal Procedure [CCP]), or who have been accused of stalking (Article 190a $\S 1$ of the Penal Code), or identity theft (Article 190a $\S 2$ of the Penal Code) motivated by the aggrieved party's occupation (Article 276a § 1a CCP).

According to the legal doctrine, this is not the introduction a new preventive measure but rather a statutory superfluum to the regulation contained in Article 275 $\S 2 \mathrm{CCP}$ that is nothing more than a casuistic list of obligations that may be imposed on the accused. ${ }^{2}$ This view is inaccurate, as this measure differs from those containing restraining or contact prohibition orders (Article $275 \S 2$ and Article $272 \mathrm{CCP}$ ). These measures concern only an aggrieved medical staff member or their assistant and are not applicable to a person accused of any other crime, but only of an offense committed against a medical staff member in connection with their provision of medical care activities or against a person assigned to assist medical staff during the performance of these activities or for the offense of stalking or identity theft because of the victim's profession. Moreover, it contains another prohibition in the form of the above-mentioned publishing prohibition. This prohibition may not be imposed on the accused as part of police supervision ${ }^{3}$ or social surety. Admittedly, Article $275 \S 1$ in fine CCP provides for the imposition of other restrictions necessary to exercise supervision over the accused. However, due to the latter restriction, it cannot be shown that this publishing prohibition is a restriction that is necessary to exercise police supervision. That being said, there is no doubt that this measure

1 Journal of Laws 2020, item 568, as amended, hereinafter: the amendment.

2 K. Dudka, [in:] Kodeks postepowania karnego. Komentarz, ed. K. Dudka, Warszawa 2020, p. 549; eadem, [in:] K. Dudka, H. Paluszkiewicz, Postępowanie karne, Warszawa 2021, p. 414; A. Ornowska, Skuteczny środek zapobiegawczy (258a k.p.k.) oraz inne nowe instytucje w k.p.k. (232b i $276 a$ k.p.k.) wprowadzone w tzw. specustawie w zwiąku z epidemia koronawirusa, LEX/el. 2020.

3 Different opinion is incorrect. See A. Ornowska, op. cit. 
is intended to protect the aggrieved party, and it is therefore rightly recognized as a new preventive measure. ${ }^{4}$

We also cannot back the view that - since this provision has been added to the Code of Criminal Procedure - Article 276a CCP applies only to the extent where it serves to combat and prevent the spread of the infectious disease known as SARS$-\mathrm{CoV}-2$ and it is not applicable to proceedings not related to combating and counteracting the coronavirus pandemic. The scope of application of Article 276a CCP remains the same regardless of the subject matter of the act, which introduced it to the Code of Criminal Procedure. It is included in the legal act regulating criminal proceedings and thus remains fully applicable.

Nevertheless, subject literature rightly points out that applying this measure in small towns may negatively result in limiting, and in extreme cases, even depriving the accused of medical care. ${ }^{5}$

\section{OBJECTIVES OF THE MEASURE}

The explanatory memorandum stresses that this measure is intended to provide special protection for healthcare professionals who are exposed to both verbal and physical attacks in connection with their work. The measure allows for taking immediate reaction in the form of preventive solutions along the lines of similar measures that apply to domestic violence cases, as set out in, i.a., Article 275a CCP. This measure is a response to repeated demands from the medical community to provide special protection for healthcare professionals who are exposed to verbal and physical attacks in connection with their work. This particularly concerns attacks on paramedics working in ambulances. The pandemic has also resulted in attacks taking place online, with people publishing doctors' personal data on online forums as part of "warnings" to avoid certain people. ${ }^{6}$

Therefore, it is clear that the purpose of this measure is not to ensure the proper conduct of criminal proceedings, but rather to protect a particular occupational group. Doing so by means of a preventive measure distorts the purpose of preventive measures, which, in accordance with Article $249 \S 1$ CCP, should be used to safeguard the correct course of legal proceedings and, in some exceptions, to prevent the accused from committing another serious crime. This results in inconsistency in

4 K. Eichstaedt, [in:] Kodeks postępowania karnego. Komentarz zaktualizowany, ed. D. Świecki, vol. 1, LEX/el. 2021, thesis 2 regarding Article 276a.

5 Ibidem, thesis 9 regarding Article 276a.

6 Autopoprawka do rządowego projektu ustawy o zmianie ustawy o szczególnych rozwiązaniach związanych z zapobieganiem, przeciwdziałaniem i zwalczaniem COVID-19, innych chorób zakaźnych oraz wywołanych nimi sytuacji kryzysowych oraz niektórych innych ustaw, Print no. 299-A, www. sejm.gov.pl/Sejm9.nsf/PrzebiegProc.xsp?nr=299 [access: 10.10.2021], p. 15. 
applying the law. ${ }^{7}$ This assessment is not changed by the wording of Article 276a $\S 4 \mathrm{CCP}$, which shows that the legislator had in mind securing the proper course of criminal proceedings, because the prohibitions contained in this measure are in no way capable of achieving this goal.

Protection of the victim's interests is undoubtedly important in criminal proceedings, as indicated in Article $2 \S 1$ (3) CCP, which requires that the legitimate interests of the victim be taken into account. Nothing stands in the way of adding the victim's protection as another objective of Article $249 \S 1 \mathrm{CCP}$. This is all the more justified since this is not the only case where legislature has infringed on the above-mentioned fundamental objectives of preventive measures. The protection of a victim's best interests was served by extending the scope of duties that may be imposed on the accused under police supervision. This includes the prohibition of contact with the victim or other persons, restraining orders ${ }^{8}$ (Article 275 § $1 \mathrm{CCP}$ ), as well as the introduction of so-called conditional police supervision, applicable provided that the accused leaves the premises they occupy jointly with the victim within the prescribed time period and determines the place of their stay ${ }^{9}$ (Article 275 $\S 3 \mathrm{CCP}$ ). The same applies to the preventive measure in the form of an order for the accused to leave the dwelling that they jointly occupy with the victim (Article 275a $\S 1 \mathrm{CCP}) .{ }^{10}$ On the other hand, the introduction of a prohibition on applying for public contracts for the duration of a legal procedure ${ }^{11}$ into the preventive measure referred to in Article $276 \mathrm{CCP}$ was intended to protect public procurement procedures and has no connection with the objectives of criminal proceedings.

\section{GENERAL PREREQUISITES}

This measure may be applied to persons accused of:

1) an offense committed against a medical staff member and in connection with the performance of their activities or those of a person assigned to assist medical staff in the performance of their activities (Article 276a § $1 \mathrm{CCP}$ ),

7 R. Koper, [in:] Kodeks postępowania karnego. Komentarz, ed. A. Sakowicz, Warszawa 2020, pp. $772-773$.

8 Act of 5 November 2009 amending the Act - Penal Code, the Act - Code of Criminal Procedure, the Act - Executive Penal Code, the Act - Fiscal Penal Code and certain other acts (Journal of Laws 2009, no. 206, item 2589).

9 Ibidem.

10 Act of 10 June 2010 on modification of the Act regarding fight against domestic violence and modification of certain other acts (Journal of Laws 2010, no. 125, item 842).

${ }^{11}$ Act of 22 June 2016 on modification of the Act - Public Contracts Law and on modification of certain other acts (Journal of Laws 2016, item 1020). 
2) an offense of stalking (Article 190a $\S 1$ of the Penal Code) or identity theft (Article 190a $\S 2$ of the Penal Code) committed because of the victim's profession (Article 276a § 1a CCP).

\section{An offense against a medical staff member or a person assigned to assist medical staff}

The legal act does not indicate the type of delinquency to be committed by the accused. Therefore, it can apply to any delinquency, regardless of its gravity i.e. both to a crime and a petty offense. The significant limiting factor here is the requirement that: firstly, the offense is committed against a medical staff member or a person assisting them; and secondly, it is in connection with both parties' performance of their medical care activities.

\subsection{Medical staff}

From a purely linguistic point of view, the term "staff" can be defined as "a team of people working in an institution who are associated by their joint professional work". ${ }^{12}$ Therefore, "medical staff" means the above-mentioned team of people but involved in medicine and the provision of healthcare services as a profession. The statutory scope of this term is not limited to medical professionals, i.e. people licensed to provide medical services on the basis of legal provisions and people who have gained professional qualifications to provide medical services within an indicated scope of a certain field of medicine (Article 2 (1) (2) of the Act of 15 April 2011 on medical activity $\left.{ }^{13}\right)$. Current judicature rightfully accepts that "the concept of 'medical staff' cannot be equated with the definition of 'medical profession' as featured in the Medical Activity Act". ${ }^{14}$ The explanatory memorandum to the Act's draft amendment stresses that the concept is "deliberately wider than that of a doctor or nurse in order to ensure the legal protection of all persons performing medical care activities. Also, this protection does not depend on where such staff works, i.e. whether in a public or a private medical facility". ${ }^{15}$

Subject literature defines a medical professional as a person with a medical education who systematically and, for a fee or free of charge in justified cases, undertakes and carries out medical activities. These, in turn, are activities carried out in person that have an impact on a patient's state of health, in correspondence

12 Praktyczny słownik współczesnej polszczyzny,ed. H. Zgółkowa, vol. 28, Poznań 2000, p. 181.

13 Journal of Laws 2011, item 711, as amended.

14 Judgement of the Voivodeship Administrative Court in Lublin of 13 December 2011, III SA/ Lu 653/11, LEX no. 1102241.

${ }^{15}$ Autopoprawka do rządowego projektu ustawy..., p. 15. 
with current requirements and medical knowledge on the basis of qualifications and skills acquired as a result of the medical professional's educational background and acquired entitlements. ${ }^{16}$ The essence of this profession is the provision of healthcare services for the preservation, rescue, restoration or improvement of a person's health, or the execution of other medical activities. ${ }^{17}$

\subsection{Persons assigned to assist medical staff}

A person assigned to assist medical staff is a person who has been assigned to perform this role and assists at the request of a medical staff member, ${ }^{18}$ or a person who, at their own initiative, provides assistance to a medical staff member given that their assistance has been accepted. ${ }^{19}$ Such assistance may take place either through a formal call for participation, or implicitly. ${ }^{20}$ These are persons who have been assigned to assist a specific medical staff member for the duration of the provision of specified healthcare activities. Such persons do not have to be assigned to a specific member of staff. Article $276 \mathrm{a} \S 1 \mathrm{CCP}$ refers to a person assigned to assist medical staff who is not a member of that staff.

Their assignment is to help the medical staff perform their activities. ${ }^{21}$ These persons do not need to take an active role - their actions can be passive, as long as the medical staff members' will was for such assistance.

\subsection{The relationship between a committed offense and the performance of} medical care activities

A specific medical care activity must be the cause of the offense committed against a medical staff member or the person assisting them. Committing an offense in broad connection with the performance of such activity, e.g. simply because a person is a doctor or a nurse, is not sufficient. It must be linked to a specific act

${ }^{16}$ D. Karkowska, Zawody medyczne, Warszawa 2012 p. 129; B. Sygit, D. Wąsik, Prawo ochrony zdrowia, Warszawa 2016, p. 159.

${ }_{17}$ M. Brzozowska-Kruczek, Zawody medyczne, Warszawa 2013, p. 200; B. Sygit, D. Wąsik, op. cit., p. 160.

18 Judgement of the Supreme Court of 28 April 1936, III K 240/36, OSN 1936, no. 11, item 417; L. Peiper, Komentarz do kodeksu karnego, Kraków 1936, p. 274.

19 E.W. Pływaczewski, E.M. Guzik-Makaruk, [in:] Kodeks karny. Komentarz, ed. M. Filar, Warszawa 2016, p. 1357; M. Kulik, [in:] Kodeks karny. Komentarz, ed. M. Mozgawa, Warszawa 2019, p. 745.

20 A. Barczak-Oplustil, M. Iwański, [in:] Kodeks karny. Część ogólna, vol. 2, part 1: Komentarz do art. 212-277d, eds. W. Wróbel, A. Zoll, Warszawa 2017, p. 148; J. Lachowski, [in:] Kodeks karny. Część szczególna, eds. M. Królikowski, R. Zawłocki, vol. 2, Warszawa 2017, p. 11; A. Lach, [in:] Kodeks karny. Komentarz, ed. V. Konarska-Wrzosek, Warszawa 2020, p. 1107.

${ }^{21}$ Judgement of the Supreme Court of 7 November 1938, III K 3139, OSN 1939, no. 6, item 154. 
taken by a medical staff member. ${ }^{22}$ This condition does not exist in a situation where a criminal offense is committed to the detriment of a medical staff member but due to private relations between said medical staff member and the accused.

It is apparent from the content of Article $276 \mathrm{a} \S 1 \mathrm{CCP}$ that in the event of an offense committed against a person assigned to assist a medical staff member, there is no required link between the offense and the performance of the assisting person's activities. This seems like the correct approach, since such a person does not have to be licensed to perform healthcare activities as their help or assistance may be of another (e.g., technical) nature. The important factor here is the relationship between this person's activities and those of a medical staff member.

The performance of medical care activities is a broader concept than the provision of a healthcare service which, as mentioned earlier, are provided for the preservation, rescue, restoration or improvement of a person's health, as well as other medical activities resulting from a healthcare treatment process or from separate provisions (Article 2 (1) (10) of the Medical Activity Act). Medical care activities - on the other hand - are also related to caring for people's health not only by means of providing direct healthcare services, but also through other activities where the ultimate goal is to preserve or improve a person's overall state of health.

In the legal proceedings, any evidence gathered must indicate a high probability that the accused has committed such an offense as described above, in accordance with Article 249 § 1 in fine CCP.

\section{Stalking or identity theft committed because of the victim's profession (Article 276a § 1a CCP)}

Article 276 § 1a CCP identifies the offense described in Article 190a of the Penal Code as a general prerequisite. In fact, Article 276 references the entire provision. This means that even its smaller sectioning levels are covered. Therefore, the reference concerns both basic offenses; including stalking (Article 190a $\S 1$ of the Penal Code) and identity theft (Article 190a $\S 2$ of the Penal Code), as well as their aggravated forms (Article 190a $\S 3$ of the Penal Code).

The offense of stalking consists of persistently harassing a person or a person close to them, resulting in the victim feeling a sense of ever-present danger, humiliation or torment, or a significant breach of privacy (Article 190a $\S 1$ of the Penal Code).

Identity theft involves impersonating another person and using their image, personal data or other data by which they are publicly identifiable for the purpose of causing material or personal harm (Article 190a $\S 2$ of the Penal Code). Aggravated offenses occur when the aforementioned acts result in the victim taking his or her own life (Article 190a $\S 3$ of the Penal Code).

${ }^{22}$ This is the Supreme Court's opinion in the light of Article 222 of the Penal Code. See decision of the Supreme Court of 11 April 2019, III KK 33/18, OSNKW 2019, no. 8, item 43. 
In the context of Article 276a $\S 1$ a CCP, Article 190a $\S 1$ of the Penal Code refers to a medical staff member. The applicability of the preventive measures discussed earlier to a person who has committed any of the aforementioned offenses against a medical staff member is limited to situations where these offense have been committed because of the victim's profession, and not for any other reason. This is supported by argumentum a rubrica. When interpreting that provision, it is impossible to disregard $\S 1$, which precedes it, which clearly states that this concerns medical staff members.

\section{SPECIAL PREREQUISITES}

Given the preventive nature of the measures discussed earlier, their application is conditional on the fulfillment of at least one special prerequisite laid down in Article 258 CCP. Moreover, given the substance of these measures, it is not justified to refer to the following - a legitimate fear of the accused escaping or hiding, especially if their identity cannot be established or they do not have a permanent place of residence in the country (Article $258 \S 1$ (1) CCP); the accused's chances of facing severe punishment (Article $258 \S 2 \mathrm{CCP}$ ); or a legitimate fear that the accused will commit another crime against life, health or public safety (Article 258 $\S 3 \mathrm{CCP}$ ). As to the latter prerequisite, it might appear that a restraining order (prohibiting the accused from approaching the victim to a predetermined distance) may work to prevent one of the above-mentioned offenses from being committed. However, its effectiveness is questionable since a restraining order does not constitute an uncrossable barrier to prevent the accused from reaching the victim. Instead, its observance is based on psychological coercion in the form of threatening the accused of taking much more severe and effective measures should it be broken (argumentum ex concessis Article 258a CCP).

The only remaining special prerequisite is the possibility of invoking a legitimate fear that the accused may try to induce the aggrieved to give false testimony (Article $258 \S 1$ (2) CCP). Then, the preventative measure of a restraining order's effectiveness would, de facto and as stated earlier, be dependent on the will of the accused to comply with the prohibition.

The difficulty in indicating a special prerequisite for the application of restraining orders is linked with their inability to achieve the main objective of a preventive measure. It appears that Article 276a CCP exhaustively regulates the basis for the application of a restraining order as a preventive measure and, in that regard, excludes the application of Article $258 \S \S 1-3 \mathrm{CCP} .{ }^{23}$ However, due to the wording of Article 276a, this is not a claim that cannot be contested.

${ }^{23}$ R. Koper, op. cit., p. 773. 


\section{THE ESSENCE OF PREVENTATIVE MEASURES}

The essence of the preventative measure consists of: 1) restraining orders; 2) contact prohibition orders; 3 ) orders prohibiting the publication, including via IT systems or telecommunications networks, of information or content that affects the legally protected interests of the aggrieved party (Article 276a § 1 CCP).

During a linguistic interpretation of Article 276a $\S 1$ CCP, we will find a comma between one prohibition and the other, which are later joined by the connective word "or", meaning that the sentence will only be true when at least one of its constituent assumptions is fulfilled, ${ }^{24}$ and clearly indicates that it is possible to decree any one of these prohibitions as well as combine them. The act does not provide for any limitations on combining prohibitions. Therefore, they may be combined in various configurations. It is for the authority applying the measure to determine the type of prohibition to be imposed on the accused. Ordering one or more of these prohibitions is mandatory since their essence is to prohibit a particular conduct. The victim's will should not matter, but it seems that the authority applying the measure should take into account the victim's opinion in this regard. Particularly when it comes to choosing the type of prohibition. In light of Article 41a $\S 2$ of the Penal Code, judicature indicates that a decision prohibiting the accused from contacting and approaching the victim - which, in principle, is intended to protect them - also affects their rights and freedoms. A restraining order put out against the accused when the victim would express a desire to remain in contact with them would undoubtedly infringe on their rights and freedoms guaranteed by law. ${ }^{25}$

\section{Restraining orders - prohibition to approach the victim within a certain distance}

To "approach" means "moving towards someone, effectively reducing your distance to them". ${ }^{26}$

The act imposes an obligation to determine the distance the accused is obliged to keep from the victim on the authority adjudicating the prohibition. This is supported by the phrase "at an indicated distance" used in Article 276a § 1 CPP. However, the act indicates neither the minimum nor the maximum of this distance. When determining the distance, the court or the prosecutor applying this measure should choose a distance that would guarantee freedom from stress for the victim - even

${ }^{24}$ W. Wolter, M. Lipczyńska, Elementy logiki. Wykład dla prawników, Warszawa-Wrocław 1973, p. 82.

${ }_{25}$ Judgement of the Court of Appeal in Wroclaw of 9 October 2012, II AKa 276/12, LEX no. 1451536.

${ }^{26}$ Praktyczny słownik współczesnej polszczyzny, ed. H. Zgółkowa, vol. 49, Poznań 2004, p. 89. 
if they were to catch sight of the accused. After all, this measure is there to save the victim the unpleasant experience of having to relive the memories of the offense committed against them, which may be triggered by meeting or seeing the accused. This prohibition should include some elasticity whilst also keeping the distance safe for the victim (e.g., not less than two meters). ${ }^{27}$

Unlike in the case of criminal measures (Article 41a $\S \S 1$ and 2 in fine of the Penal Code), the legislator did not provide for the monitoring of compliance with this prohibition by means of an electronic surveillance system, which could be carried out in the form of proximity surveillance (Article 43b $\S 3$ (3) of the Executive Penal Code). Such a solution would serve to strengthen the effectiveness of this measure and should be called for.

\section{Prohibition of establishing contact with the victim}

The word "contact" means "touch, approach, connection, communication enabling interaction, connection, relationship". "To contact" - "establish, maintain contacts with people or institutions [...] establish, maintain mutual contacts". ${ }^{28}$ Keeping the linguistic definitions of these terms in mind, subject literature assumes that "contact" is a matter of establishing or maintaining certain relationships which are deliberate, thought out, intentional and planned. This speaks in favor of excluding random meetings of the accused and the victim, e.g. in a park or shopping mall. ${ }^{29}$ Article 276a $\S 1 \mathrm{CCP}$ mentions "prohibition of contact". However, there is no quantification, which indicates that the legislator meant contact in general, on any grounds, e.g. private, business or professional. ${ }^{30}$ This prohibition is of a generalized nature.

It can include touching, making gestures, talking to, calling, sending letters, text messages, e-mails, and so on. ${ }^{31}$ Differentiation of contact is not possible, e.g. by limiting it to private or personal and omitting other fields or forms.

Being in the vicinity of the victim alone is not enough to be defined as "contact". Contact is active conduct. The aim here is for the accused not to intentionally establish and maintain any relations with the victim. ${ }^{32}$

${ }^{27}$ W. Zalewski, [in:] Kodeks karny. Część ogólna. Komentarz. Art. 1-116, eds. M. Królikowski, R. Zawłocki, Warszawa 2017, p. 684.

${ }_{28}$ Stownik wspótczesnego języka polskiego, ed. B. Dunaj, Warszawa 2007, p. 240.

29 A. Ziółkowska, [in:] Kodeks karny..., p.292.

${ }_{30}$ W. Zalewski, op. cit., p. 683; R.A. Stefański, [in:] Kodeks karny. Komentarz, ed. M. Filar, p. 248; A. Ziółkowska, op. cit., p. 292.

${ }^{31}$ M. Kulik, [in:] Środki karne, przepadek i środki kompensacyjne w znowelizowanym kodeksie karnym, ed. P. Daniluk, Warszawa 2017, p. 130.

32 R.A. Stefański, [in:] Kodeks karny. Komentarz, ed. R.A. Stefański, Warszawa 2020, p. 412. 


\section{Prohibition on publishing content affecting the legally protected interests of the aggrieved party}

The publication prohibition is limited to content which undermines the legally protected interests of the victim. As stated in the explanatory memorandum to the amendment, this prohibition is based on the safeguard in civil proceedings in cases concerning the protection of personal rights and consisting of publication prohibitions, as set out in Article $755 \S 2$ of the Civil Procedure Code. ${ }^{33}$ Its purpose is to prevent the infringement of legally protected interests in the form of reverence, image, privacy and other personal rights that may be infringed upon by the publication of press materials or radio or television broadcasts.

Prohibition of publication means a prohibition on the use of certain wording or the reproduction of certain works in tangible media, and making such work available to the public. ${ }^{34}$

According to Article 2 (2) of the Act of 7 November 1996 on compulsory library copies, ${ }^{35}$ publication is any content reproduced using any technique for the purpose of distribution, particularly: 1) literature, such as books, brochures, newspapers, magazines and other periodicals, leaflets, posters; 2) materials featuring graphical and text content such as maps, posters, plans, charts, tables, drawings, illustrations, sheet music; 3) audiovisual recordings of sounds, images or images and sounds, such as CDs, tapes, cassettes, slides, microfilms, microfiche; 4) recordings on IT data carriers; 5) computer software. This definition does not cover online communication via the Internet. It is therefore correct that Article 276a $\S 1$ CCP narrows the issue down and includes publishing content by means of IT systems or telecommunications networks. Furthermore, the publication prohibition, in accordance with Article 276a $\S 3 \mathrm{CCP}$, includes a prohibition on publishing and making content available regardless of whether it has been produced by the accused or somebody else, through online portals and websites, which constitute a service provided electronically. The provision of services by electronic means is the provision of services without the simultaneous presence of either parties (over distance) via data transmission at the request of the recipient, transmitted and received by means of electronic processing equipment, including the digital compression and storage of data, which is fully sent, received or transmitted by means of a telecommunications network (Article 2 (4) of the Act of 18 July 2002 on providing services by electronic means ${ }^{36}$ ). The fact that the provisions of this Act

\footnotetext{
${ }^{33}$ Autopoprawka do rządowego projektu ustawy..., p. 15.

34 E. Czarny-Drozdzejko, Zakaz publikacji jako zabezpieczenie powództwa w sprawach cywilnych skierowanych przeciwko prasie, "Przegląd Sądowy" 2014, no. 1, p. 51.

${ }_{35}$ Journal of Laws 2018, item 545.

36 Journal of Laws 2020, item 344.
} 
- in accordance with Article 3 thereof - do not apply to the use of e-mail or other equivalent means of electronic communication between natural persons for personal purposes not related to the gainful activities they carry out, even if related to their profession (point 2) and the provision of electronic services carried out within the organizational structure of the service provider, whereby the service provided by electronic means is used exclusively to manage work or other processes of that entity (point 6), it cannot be concluded that the prohibition does not apply to these types of electronic communication, e.g. private information transmitted by individuals via instant messaging software such as Messenger. ${ }^{37}$ The reference to this law does not imply its application in its entirety, but only concerns the definition of a service provided by electronic means.

\section{COMBINING PREVENTATIVE MEASURES WITH BAIL BONDS}

Prohibitions, in accordance with Article 276a § 2 CCP, may be combined with a bail bond. This does not mean, however (as has been wrongly assumed in subject literature) that doing so gives them a more complex form. ${ }^{38}$ Such a definition is inaccurate and a bail bond is adjudicated alongside the preventative measures discussed earlier.

A bail bond is a precautionary measure, as indicated by the reference to apply Articles 266-270 CCP explicitly and not respectively. This regulation constitutes a superfluum, since surety may be applied in addition to that preventive measure on a general basis; non-isolating preventive measures may be cumulative..$^{39}$ The novum here is that the assets or liabilities which are the subject of the bail are forfeited or withheld in the case of not complying with the prohibitions. This is an additional circumstance, besides escape or having the accused go into hiding (Article 268 $\S 1 \mathrm{CCP}$ ), which causes the obligatory forfeiture of property or liabilities or the collection of the bail bond. For this reason, the surety is falsely treated as a special variation of bail. ${ }^{40}$ This would be true if the provision modified it accordingly however in this case, matters concern circumstances following its application.

It is sufficient to disobey the prohibitions once.

If several prohibitions are imposed, it is sufficient not to comply with just one of them. It is not possible to endorse the view that it does not give rise to a compulsory forfeiture or recovery of the bail bond and may constitute a condition for an

\footnotetext{
${ }^{37}$ K. Dudka, [in:] Kodeks ..., p. 551.

${ }^{38}$ R. Koper, op. cit., p. 774.

${ }^{39}$ K. Dudka, [in:] Kodeks ..., p. 550.

${ }^{40}$ R. Koper, op. cit., p. 774.
} 
optional forfeiture order as another means of obstructing proceedings ${ }^{41}$ And although Article 276a $\S 2$ CCP refers to non-compliance with prohibitions - that is to say in plural form - it cannot be concluded that we are talking about a breach of at least two prohibitions. The Supreme Court aptly explained that: "The mere use of a plural in the wording of a legal standard to determine the subject-matter of direct protection, the subject-matter of an act of conduct or a measure used to commit criminal offense does not mean that the legislator uses it in the sense of "at least two"". ${ }_{42}$

\section{ADJUDICATION PROCEDURES}

The application of the measure in question is optional, irrespective of the accusations that have been made against the accused. Both $\S 1$ and $\S 2$ of Article 276a $\mathrm{CCP}$ describe this conduct of procedural authorities with the phrase: "may adjudicate," which signifies the possibility of taking such a decision.

\section{THE PERIOD OF APPLICATION OF PREVENTATIVE MEASURES}

The above-mentioned measures are of a temporary nature during pre-trial proceedings. Although Article 276a $\S \S 4$ and 5 CCP refers to the duration of the prohibitions and not of preventive measures, its substance is prohibitions and these cannot be applied without imposing at least single prohibition, therefore we can assume that the measures themselves are of a prohibitory nature.

The view that the measure is temporary only in preparatory proceedings is supported by the fact that its extension has been regulated in Article 276a $\$ 5$ CCP. Under this provision, the district court may - at the request of the public prosecutor - extend prohibitions further to a period exceeding a total of 6 months in preparatory proceedings. A contrario, we can draw the conclusion that there is no such need in judicial proceedings. In addition, there is no specified period of application of

${ }^{41}$ K. Dudka, [in:] Kodeks..., p. 550.

42 Resolution of the Supreme Court of 21 November 2001, I KZP 26/01, OSNKW 2002, no. 1-2, item 4 with approval commentaries of P. Palka and M. Przetak (Glosa do uchwaty SN z dnia 21 listopada 2001 r., I KZP 26/01, "Przegląd Sądowy" 2003, no. 11-12, p. 181 ff.), W. Marcinkowski (Glosa do uchwaty SN z dnia 21 listopada 2000 r., I KZP 26/01, "Prokurator" 2002, no. 2, pp. 104-115), partially critical commentary of O. Sitarz (Glosa do uchwaty SN z dnia 21 listopada $2000 \mathrm{r}$., I KZP 26/01, "Państwo i Prawo" 2003, no. 10, pp. 127-130) and M. Klubińska (Glosa do uchwały SN z dnia 21 listopada 2000 r., I KZP 26/01, "Prokuratura i Prawo" 2003, no. 12, pp. 107-111), and approval commentary of R.A. Stefański (Przeglad uchwat Izby Karnej Sądu Najwyższego w zakresie prawa karnego materialnego, prawa karnego wykonawczego i prawa wykroczeń za 2001 r., "Wojskowy Przegląd Prawniczy" 2002, no. 1, pp. 141-143). 
prohibitions in legal proceedings. ${ }^{43}$ In the legal doctrine, it has been unduly assumed that the designation period also applies to jurisdictional proceedings. ${ }^{44}$

Article 276a § 4 CCP does not specify the period that prohibitions can be imposed for expressis verbis. The fact that they can be applied for a period of up to 6 months is due to $\S 5$ of this provision, which allows for the extension of the prohibition for a further period exceeding a total of 6 months. This means that the authority imposing the prohibition is obliged to determine its period of application to be no longer than 6 months. It can be further imposed, not extended, ${ }^{45}$ since an extension can only take place only after 6 months. Extensions may be repeated multiple times. ${ }^{46}$

The time period of a prohibition's application is determined after taking into account the security requirements of the course of the criminal proceedings and providing the victim and their next of kin with appropriate protection (Article 276a $\S 3 \mathrm{CCP}$ ). That being said, it is incomprehensible why this provision mentions the protection of the victims next of kin as a circumstance for determining the duration of the prohibitions, since Article $276 \mathrm{a} \S 1 \mathrm{CCP}$ does not mention the need to protect persons closest to the victim.

\section{CONCLUSIONS}

Article 276a CCP regulates a new preventive measure in the form of a restraining order, a contact prohibition order and an order prohibiting the publication of materials related to medical staff members or persons assigned to assist them. The objective of these new measures is to protect medical staff and the people assisting them - it is not to secure an effective course of legal proceedings, and neither is it to prevent the accused from committing new crimes. This leads to a breach of the coherence of this preventive measure system. Nevertheless, the victims' rights also need to be protected by means of such measures, which in turn gives rise to the question of possible de lege ferenda, i.e. to add victim protection as a further objective of these measures to Article $249 \S 1$ CCP. The catalog of prohibitions listed in Article 276a § $1 \mathrm{CCP}$ is comprehensive (numerus clausus). One, more, or even all prohibitions may be imposed on the accused. But since the substance of these measures is the prohibition of particular conduct, at least one of them is required. These measures are temporary during preparatory proceedings, but not during judiciary proceedings. This argument is supported by Article 276a $\S 4$ CCP which

\footnotetext{
${ }^{43}$ K. Eichstaedt, op. cit., thesis 7 regarding Article 276a.

${ }^{44}$ K. Dudka, [in:] Kodeks ..., p. 55; R. Koper, op. cit., p. 774.

45 This is the opinion of R. Koper (op. cit., p. 774).

46 Ibidem, p. 775.
} 
does not regulate the prohibition period; and by Article 276a §5 CCP determining that prohibition extensions can happen only during preparatory proceedings (not referring to judicial proceedings at all).

\section{REFERENCES}

\section{Literature}

Barczak-Oplustil A., Iwański M., [in:] Kodeks karny. Część ogólna, vol. 2, part 1: Komentarz do art. 212-277d, eds. W. Wróbel, A. Zoll, Warszawa 2017.

Brzozowska-Kruczek M., Zawody medyczne, Warszawa 2013.

Czarny-Drożdżejko E., Zakaz publikacji jako zabezpieczenie powództwa w sprawach cywilnych skierowanych przeciwko prasie, "Przegląd Sądowy" 2014, no. 1.

Dudka K., [in:] Kodeks postepowania karnego. Komentarz, ed. K. Dudka, Warszawa 2020.

Dudka K., [in:] K. Dudka, H. Paluszkiewicz, Postepowanie karne, Warszawa 2021.

Eichstaedt K., [in:] Kodeks postępowania karnego. Komentarz zaktualizowany, ed. D. Świecki, vol. 1, LEX/el. 2021.

Karkowska D., Zawody medyczne, Warszawa 2012.

Klubińska M., Glosa do uchwały SN z dnia 21 listopada 2000 r., I KZP 26/01, "Prokuratura i Prawo" 2003, no. 12.

Koper R., [in:] Kodeks postępowania karnego. Komentarz, ed. A. Sakowicz, Warszawa 2020.

Kulik M., [in:] Kodeks karny. Komentarz, ed. M. Mozgawa, Warszawa 2019.

Kulik M., [in:] Środki karne, przepadek i środki kompensacyjne w znowelizowanym kodeksie karnym, ed. P. Daniluk, Warszawa 2017.

Lach A., [in:] Kodeks karny. Komentarz, ed. V. Konarska-Wrzosek, Warszawa 2020.

Lachowski J., [in:] Kodeks karny. Czesść szczególna, eds. M. Królikowski, R. Zawłocki, vol. 2, Warszawa 2017.

Marcinkowski W., Glosa do uchwaty SN z dnia 21 listopada 2000 r., I KZP 26/01, "Prokurator" 2002, no. 2.

Ornowska A., Skuteczny środek zapobiegawczy (258a k.p.k.) oraz inne nowe instytucje w k.p.k. (232b i $276 a$ k.p.k.) wprowadzone $w$ tzw. specustawie w zwiazku z epidemia koronawirusa, LEX/el. 2020.

Palka P., Przetak M., Glosa do uchwaty SN z dnia 21 listopada 2001 r., I KZP 26/01, "Przegląd Sądowy" 2003, no. 11-12.

Peiper L., Komentarz do kodeksu karnego, Kraków 1936.

Pływaczewski E.W., Guzik-Makaruk E.M., [in:] Kodeks karny. Komentarz, ed. M. Filar, Warszawa 2016.

Praktyczny słownik współczesnej polszczyzny, ed. H. Zgółkowa, vol. 28, Poznań 2000.

Praktyczny słownik współczesnej polszczyzny, ed. H. Zgółkowa, vol. 49, Poznań 2004.

Sitarz O., Glosa do uchwaty SN z dnia 21 listopada 2000 r., I KZP 26/01, "Państwo i Prawo" 2003, no. 10.

Słownik wspótczesnego języka polskiego, ed. B. Dunaj, Warszawa 2007.

Stefański R.A., Przeglad uchwat Izby Karnej Sąu Najwyższego w zakresie prawa karnego materialnego, prawa karnego wykonawczego i prawa wykroczeń za 2001 r., "Wojskowy Przegląd Prawniczy" 2002, no. 1.

Stefański R.A., [in:] Kodeks karny. Komentarz, ed. M. Filar, Warszawa 2016. 
Stefański R.A., [in:] Kodeks karny. Komentarz, ed. R.A. Stefański, Warszawa 2020.

Sygit B., Wąsik D., Prawo ochrony zdrowia, Warszawa 2016.

Wolter W., Lipczyńska M., Elementy logiki. Wykład dla prawników, Warszawa-Wrocław 1973.

Zalewski W., [in:] Kodeks karny. Część ogólna. Komentarz. Art. 1-116, eds. M. Królikowski, R. Zawłocki, Warszawa 2017.

Ziółkowska A., [in:] Kodeks karny. Komentarz, ed. V. Konarska-Wrzosek, Warszawa 2020.

\section{Online sources}

Autopoprawka do rządowego projektu ustawy o zmianie ustawy o szczególnych rozwiązaniach związanych z zapobieganiem, przeciwdziałaniem i zwalczaniem COVID-19, innych chorób zakaźnych oraz wywołanych nimi sytuacji kryzysowych oraz niektórych innych ustaw, Print no. 299-A, www.sejm.gov.pl/Sejm9.nsf/PrzebiegProc.xsp?nr=299 [access: 10.10.2021].

\section{Legal acts}

Act of 7 November 1996 on compulsory library copies (Journal of Laws 2018, item 545).

Act of 18 July 2002 on providing services by electronic means (Journal of Laws 2020, item 344).

Act of 5 November 2009 amending the Act - Penal Code, the Act - Code of Criminal Procedure, the Act - Executive Penal Code, the Act - Fiscal Penal Code and certain other acts (Journal of Laws 2009, no. 206, item 2589).

Act of 10 June 2010 on modification of the Act regarding fight against domestic violence and modification of certain other acts (Journal of Laws 2010, no. 125, item 842).

Act of 15 April 2011 on medical activity (Journal of Laws 2011, item 711, as amended).

Act of 22 June 2016 on modification of the Act - Public Contracts Law and on modification of certain other acts (Journal of Laws 2016, item 1020).

Act of 31 March 2020 amending the Act on special solutions related to the prevention, counteracting and combating of COVID-19, other infectious diseases and related crisis situations, and certain other acts (Journal of Laws 2020, item 568, as amended).

\section{Case law}

Decision of the Supreme Court of 11 April 2019, III KK 33/18, OSNKW 2019, no. 8, item 43.

Resolution of the Supreme Court of 21 November 2001, I KZP 26/01, OSNKW 2002, no. 1-2, item 4. Judgement of the Court of Appeal in Wrocław of 9 October 2012, II AKa 276/12, LEX no. 1451536. Judgement of the Supreme Court of 28 April 1936, III K 240/36, OSN 1936, no. 11, item 417. Judgement of the Supreme Court of 7 November 1938, III K 3139, OSN 1939, no. 6, item 154. Judgement of the Voivodeship Administrative Court in Lublin of 13 December 2011, III SA/Lu 653/11, LEX no. 1102241.

\section{ABSTRAKT}

Artykuł ma charakter naukowo-badawczy, a jego przedmiotem jest wprowadzony ustawą z dnia 31 marca 2020 r. nowy środek zapobiegawczy stosowany wobec oskarżonego o przestępstwo popełnione w stosunku do członka personelu medycznego w związku z wykonywaniem przez niego czynności opieki medycznej lub osoby przybranej personelowi medycznemu do pomocy w związku z wykonywaniem tych czynności. Podstawowym celem naukowym była ocena zasadności jego wpro- 
wadzania do procesu karnego i poprawności określenia dodatkowych przesłanek jego stosowania, a także jego zakresu przedmiotowego. Celem głównych tez badawczych było wykazanie, że środek ten, mimo negowania w doktrynie jego wprowadzenia do Kodeksu postępowania karnego, może odegrać istotną rolę w zapewnieniu bezpieczeństwa członkom personelu medycznego, chociaż ten cel nie jest adekwatny do ogólnych celów środków zapobiegawczych, a także wskazanie koniecznych zmian legislacyjnych, mających usunąć niespójność kodeksową wywołaną jego błędnym unormowaniem. Wyniki badania mają oryginalny charakter, gdyż mimo krótkiego obowiązania analizowanej regulacji wykazały potrzebę interwencji ustawodawcy. Badania mają przede wszystkim zasięg krajowy, ale mogą być przydatne również w innych państwach ze względu na to, że dotyczą oryginalnego środka zapobiegawczego, który wykracza poza tradycyjne rozumienie tego rodzaju środków. Opracowanie ma istotne znaczenie dla nauki, gdyż zawiera pogłębioną analizę dogmatyczną i duży ładunek myśli teoretycznej, a także dla praktyki, wskazuje bowiem kierunki interpretacji przesłanek stosowania środka zapobiegawczego i innych jego elementów, a tym samym może przyczynić się do jego jednolitego stosowania.

Słowa kluczowe: członek personelu medycznego; opieka medyczna; osoba przybrana do czynności; środek zapobiegawczy; zakaz kontaktów; zakaz publikacji; zakaz zbliżania się 